\title{
PENINGKATAN HASIL BELAJAR KIMIA MATERI POKOK IKATAN KIMIA MELALUI PEMBELAJARAN KONTEKSTUAL DENGAN METODE KERJA KELOMPOK PADA SISWA KELAS X DI MAN KOTA SORONG
}

\author{
Nurhaeda
}

\author{
MAN Kota Sorong
}

\begin{abstract}
ABSTRAK
Penelitian bertujuan untuk mengetahui peningkatan hasil belajar siswa kelas X setelah diterapkan pembelajaran kontekstual dengan metode kerja kelompok materi pokok ikatan kimia semester gasal MAN Kota Sorong Tahun Ajaran 2019/2020. Penelitian ini merupakan penelitian tindakan kelas (Classroom Action Research) yang dilaksanakan dalam 2 siklus. Subyek penelitian adalah siswa kelas X MAN Kota Sorong pada semester ganjil dengan jumlah siswa sebanyak 40 orang. Prosedur penelitian terdiri dari 4 tahap di setiap siklusnya, yakni perencanaan, pelaksanaan tindakan, observasi dan refleksi. Proses pembelajaran kimia dilaksanakan dengan menggunakan pendekatan kontekstual dengan metode kerja kelompok. Metode pengumpulan datanya berupa, metode observasi, dokumentasi, serta metode tes. Analisa data menggunakan pendekatan kontekstual. Penelitian ini dilaksanakan dalam dua tahap yaitu tahap siklus I dan siklus II. Hasil penelitian diperoleh pada siklus I nilai tertinggi 96 dan terendah 46 Rata-rata kelas pada siklus I 67 dan, pada siklus I keaktifan siswa sebesar $65 \%$. Kinerja guru pada siklus I memperoleh nilai 62\%. Dilihat dari indicator keberhasilan, siklus I kurang berhasil dan perlu perbaikan pada siklus II. Pada siklus nilai tertingi 96 dan terendah 56, rata-rata kelas pada siklus II 73. Sedangkan keaktifan siswa sebesar $86 \%$ dan kinerja guru sebesar $84 \%$. Maka pada siklus II sudah berhasil. Hasil penelitian yang dilakukan oleh peneliti membuktikan bahwa ada peningkatan hasil belajar siswa setelah mengikuti pembelajaran melalui pendekatan kontekstual dengan metode kerja kelompok, ini dapat dilihat dari keaktifan siswa, kinerja guru, rata-rata nilai siswa dan ketuntasan hasil belajar siswa. Hasil penelitian ini di harapkan dapat memberikan sumbangan pemikiran bagi upaya peningkatan mutu pembelajaran yang dilaksanakan guru maupun lembaga yang bersangkutan.
\end{abstract}

\section{PENDAHULUAN}

Perkembangan IPA yang begitu pesat, menggugah pendidik untuk merancang dan melaksanakan pendidikan yang lebih terarah pada penguasaan konsep IPA, yang dapat menunjang kegiatan sehari-hari dalam masyarakat. Untuk dapat menyesuaikan perkembangan IPA kreativitas sumber daya manusia merupakan syarat yang mutlak untuk di tingkatkan. Jalur yang tepat untuk meningkatkan sumber daya manusia adalah melalaui jalur pendidikan (Masnur Muslich, 2008).

Menurut UU No.20 th 2003 bahwa pendidikan adalah usaha sadar dan terencana untuk mewujudkan suasana belajar dan proses pembelajaran agar peserta didik secara aktif mengembangkan potensi dirinya untuk memiliki kekuatan spiritual keagamaan, pengendalian diri, kepribadian, kecerdasan, akhlak mulia, serta ketrampilan yang diperlukan dirinya, masyrakat, bangsa, dan Negara (Hasbulah. 2005). Selain itu pendidikan juga mempunyai arti usaha untuk menumbuh kembangkan potensi sumber daya manusia melalui kegiatan pengajaran. Pendidikan memegang peranan penting dalam mencerdaskan kehidupan bangsa, oleh karena itu setiap individu yang terlibat dalam pendidikan dituntut berperan secara maksimal guna meningkatkan mutu pendidikan. Upaya-upaya untuk meningkatkan mutu pendidikan tersebut salah satunya dengan menerapkan strategi pembelajaran yang efektif yang sesuai dengan pembelajaran siswa aktif.

Belajar merupakan kegiatan yang berproses dan merupakan unsur yang fundamental dalam setiap penyelenggaraan jenis dan jenjang pendidikan. Ini berarti bahwa berhasil atau gagalnya pencapain tujuan pendidikan itu amat bergantung pada proses belajar yang dialami siswa, baik ketika ia berada disekolah maupun dilingkungan rumah atau keluarganya sendiri. Oleh karenanya, pemahaman yang benar mengenai arti belajar dengan segala aspek, bentuk dan manifestasinya mutlak di lakukan oleh para pendidik khususnya para guru. Kekeliruan persepsi mereka terhadap proses belajar dan hal-hal yang berkaitan denganya mungkin akan mengakibatkan kurang bermutunya hasil pembelajarn yang dicapai siswa (Muhibbin Syah, 2000).

Keberhasilan proses belajar di pengaruhi oleh banyak faktor, salah satunya adalah strategi belajar mengajar yang digunakan oleh guru. Guru memiliki peran yang sangat penting dalam menentukan kualitas dan kuantitas pengajaran yang dilakukanya. Oleh sebab itu guru harus memikirkan dan membuat perencanaan secara seksama dalam meningkatkan kesempatan belajar bagi siswanya dan memperbaiki kualitas mengajarnya (Moh.Uzer Usman, 2000). Guru yang progresif berani mencoba metode-metode yang baru yang dapat membantu meningkatkan kegiatan belajar mengajar dan meningkatkan motivasi siswa untuk belajar. Agar siswa dapat belajar dengan baik, maka mengajar harus diusahakan yang tepat, efisien, dan seefektif mungkin.

Dari hasil wawancara dengan guru MAN Kota Sorong, di peroleh keterangan bahwa pembelajaran di sekolah tersebut menggunakan metode ceramah, sehingga siswa dalam kegiatan belajar 
mengajar menjadi bosan, mengantuk, serta cenderung pasif. Siswa hanya mengambil peranan yang sedikit dalam kegiatan belajar mengajar. Siswa lebih banyak berperan sebagai pendengar atau pencatat dan mengerjakan tugas dari guru. Dengan hanya menyimak ceramah yang dilakukan guru, akan membuat siswa beranggapan banyaknya fakta, konsep dan teori dalam pembelajaran kimia.

Salah satu pendekatan yang dapat digunakan untuk meningkatkan hasil belajar kimia siswa adalah pendekatan kontekstual (Contextual Teaching and Learning) dengan mengunakan metode kerja kelompok. Konsep pembelajaran ini membantu guru mengaitkan antara materi yang diajarkan dengan situasi dunia nyata atau kehidupan sehari-hari siswa dan mendorong siswa membuat hubungan antara pengetahuan yang dimilikinya dengan penerapannya dalam kehidupan mereka sebagai anggota keluarga dan masyrakat serta diharapkan seorang siswa bisa bekerja ataupun berdiskusi dengan temanya agar lebih mudah menyelesaikan suatu masalah. Melalaui konsep itu, hasil pembelajaran diharapkan lebih bermakna bagi siswa (Johson, Elaine, 2007). Sesuai dengan rumusan masalah di atas, maka tujuan penulis mengadakan penelitian ini adalah, untuk mengetahui apakah pembelajaran dengan metode kerja kelompok dapat meningkatkan hasil belajar kimia siswa kelas $\mathrm{X}$ MAN Kota Sorong.

\section{METODE PENELITIAN}

Metode penelitian yang penulis gunakan dalam penelitian ini adalah merupakan penelitian tindakan kelas (classroom action research). PTK sendiri memiliki tujuan untuk memperbaiki berbagai persoalan nyata dan praktis dalam peningkatan mutu pembelajaran, meningkatkan profesionalisme, dan menumbuhkan budaya akademik di kelas yang dialami langsung dalam interaksi antara guru dan siswa yang sedang belajar1 Dalam penelitian PTK peneliti melakukan suatu tindakan, yang secara khusus diamati secara terus-menerus, dilihat kelebihan dan kekurangannya, kemudian diadakannya pengubahan terkontrol sampai pada upaya maksimal dalam bentuk tindakan yang paling tepat. Penelitian ini menggunakan tes, dan observasi sebagai alat pengumpulan data yang pokok.

Setting atau lokasi penelitian ini dilakukan di MAN Kota Sorong pada tanggal 1 Agustus - 2 September 2019 Subyek pelaku tindakan adalah peneliti dibantu dengan guru kimia kelas $X$. Sedangkan subyek penerima tindakan adalah siswa kelas X. semester I tahun pelajaran 2019/2020 dengan jumlah siswa 40.

Metode pengumpulan data yaitu metode yang digunakan untuk memperoleh suatu data atau hasil baik melalui pengamatan, dokumentasi, ataupun tes. Metode pengumpulan data yang digunakan peneliti meliputi: metode observasi, metode dokumentasi, dan metode tes.

Metode analisis yang digunakan merupakan analisis yang mampu mendukung tercapainya tujuan dari kegiatan penelitian, berdasarkan tujuan dasar yang ingin dicapai yaitu menambah keaktifan siswa dalam kegiatan

belajar mengajar, kinerja guru meningkat, dan peningkatan hasil belajar siswa dalam materi ikatan kimia.

1. Analisis yang digunakan secara umum terdiri dari proses analisis untuk menghitung prosentase keaktifan siswa, dan mengetahui tingkat hasil belajar siswa. Untuk mengetahui seberapa besar kinerja guru ketika proses belajar mengajar berlangsung, analisis ini dilakukan pada instrument lembar observasi dengan menggunakan teknik deskriptif melalui persentase.

2. Data keaktifan siswa. Untuk mengetahui seberapa besar keaktifan siswa dalam mengikuti proses belajar mengajar berlangsung. Analisis ini dilakukan pada instrumen lembar observasi dengan menggunakan teknik deskriptif melalui prosentase.

3. Data hasil evaluasi siswa. Hasil evaluasi siklus tiap siswa diperoleh dari nilai tes akhir siklus berupa 10 soal essay. Kemudian dari data yang diperoleh dapat dianalisis nilai rata-rata tes secara klasikal dan ketuntasan belajar siswa.

Indikator keberhasilan penelitian ini adalah 1). Hasil belajar pokok materi ikatan kimia dapat meningkat. Hasil belajar yang dimaksud adalah nilai tes tertulis pada setiap akhir siklus mencapai rata-rata 7,0 untuk setiap siswa. Setelah itu pembelajaran dikatakan berhasil jika 30 orang siswa dari 40 siswa mencapai nilai 3 6,5. 2). Keaktifan belajar siswa meningkat. Pembelajaran siswa dikatakan berhasil jika keaktifan siswa memperoleh prosentase $\geq 71 \%$ atau dikategorikan baik.

\section{PEMBAHASAN}

Penelitian ini menggunakan penelitian tindakan kelas, dengan subjek satu kelas yang berjumlah 40 siswa, dan dilakukan dalam dua siklus yaitu siklus I dan siklus II. Sebelum penelitian, terlebih dahulu diadakan observasi untuk mengetahui kondisi awal siswa sebelum memperoleh penerapan pembelajaran kontekstual dengan metode kerja kelompok. Pada observasi tersebut didapati siswa kurang antusias dalam mengikuti kegiatan pembelajaran kimia karena guru masih menggunakan metode ceramah yang membosankan dan hasil belajar kimia siswa belum mencapai KKM yaitu 65 .

Perbedaan pelaksanaan pembelajaran siklus I dan II pada system pembelajaranya, ini terlihat pada pembelajaran pada siklus I kurang berhasil ini dikarenakan kurang efektifnya pembelejaran, dan dalam pengaplikasian materi dalam kehidupan seharihari kurang mengena, dikarenakan siswa belum melihat langsung sehingga mereka masih berimajinasi mengenai contoh-contoh materi ikatan kimia. Untuk pada penelitian siklus II peneliti beserta guru kimia melakukan perubahan sistem pembelajaran yang dilakukan tetapi tetap menggunakan pembelajaran kontekstual dengan metode kerja kelompok. 
Perbedaan yang ada pada siklus I dan siklus II terletak pada system pembelejarannya. Pada siklus II sistem pembelajaran yang digunakan ditekankan pada contoh-contoh langsung dalam kehidupan sehari-hari seperti contoh praktek bagaimana pembuatan kristal garam, sehingga pembelajaran yang dilakukan tidak dalam kelas melainkan di luar kelas, sehingga siswa lebih santai tetapi juga serius dalam kegiatan belajarmengajar, sehingga tercapai keberhasilan. Hasil pengamatan yang dilakukan pada siklus I dan siklus II menunjukkan keberhasilan penerapan pembelajaran kontekstual dengan metode kerja kelompok. Keberhasilan pembelajaran ditentukan oleh siswa dan guru. Ada beberapa faktor dari dalam siswa dan guru yang mempengaruhi proses pembelajaran ini.

Faktor siswa dalam pembelajaran yang dimaksud yaitu keaktifan siswa terhadap pembelajaran kimia. Berdasarkan hasil pengamatan keaktifan siswa siklus I dan siklus II, maka diperoleh data sebagai berikut:

Tabel 1 Perbandingan Keaktifan Siswa

\begin{tabular}{|l|l|}
\hline Keaktifan Siswa & Persentase \\
\hline Siklus I & $65 \%$ \\
\hline Siklus II & $86 \%$ \\
\hline
\end{tabular}

Hasil pengamatan keaktifan siswa siklus I menunjukkan kurangnya kerjasama siswa dalam kelompok presentasi. Hal ini mengakibatkan tidak semua anggota kelompok presentasi yang aktif menjawab pertanyaan dari kelompok lain. Selain itu banyak siswa yang kurang antusias mengikuti pelajaran kimia. Keberhasilan proses pembelajaran pada siklus I yang dilihat dari keaktifan siswa memperoleh persentase $65 \%$ sehingga pembelajaran belum berhasil. Hasil keaktifan siswa pada siklus I direfleksikan pada siklus II. Kekurangan pada siklus I dijadikan masalah untuk perbaikan pada siklus II .

Hasil pengamatan keaktifan siswa pada siklus II menunjukkan peran serta siswa dalam kelompoknya lebih aktif, kerjasama siswa dalam kelompoknya meningkat sehingga banyak ide - ide yang diungkapkan untuk menyelesaikan permasalahan, hal ini ditunjang dengan berjalan baik proses tanya jawab yang diberikan, banyak siswa yang berani bertanya dan mengungkapkan pendapat pada kelompok presentasi. Hasil presentasi yang dilakukan siswa dianalisis dengan baik oleh guru sehingga siswa mampu menyimpulkan materi dengan

baik dan benar. Keberhasilan proses pembelajaran pada siklus II yang dilihat dari keaktifan siswa memperoleh prosentase keberhasilan sebesar 86\% sehingga keaktifan siswa dalam pembelajaran berlangsung dengan baik.

Peranan yang sesuai antara guru dan murid mengakibatkan hasil belajar yang baik. Peranan antara guru dan murid tertera pada lampiran 8,9,10 dan lampiran 11. Ketidaksesuaian peranan guru dan murid pada siklus I,

kurangnya motivasi yang diberikan guru, analisa hasil pekerjaan siswa kurang jelas, kestabilan dan kontrol diri yang kurang, banyak siswa tidak memperhatikan pelajaran dan sibuk dengan dirinya sendiri.

Ketidaksesuaian peranan ini dapat juga terlihat dari hasil belajar yang diperoleh siswa. Berdasarkan hasil pengamatan hasil tes evaluasi, kondisi awal, siklus I dan siklus II, dapat dilihat Tabel 2 sebagai berikut:

Tabel 2 Perbandingan Tes Akhir Siswa

\begin{tabular}{|l|l|l|l|}
\hline & $\begin{array}{l}\text { Kondisi } \\
\text { Awal }\end{array}$ & $\begin{array}{l}\text { Siklus } \\
\text { I }\end{array}$ & $\begin{array}{l}\text { Siklus } \\
\text { II }\end{array}$ \\
\hline $\begin{array}{l}\text { Rata-rata hasil } \\
\text { belajar }\end{array}$ & 57 & 67 & 73 \\
\hline $\begin{array}{l}\text { Siswa yang } \\
\text { tuntas belajar }\end{array}$ & 8 & 26 & 30 \\
\hline
\end{tabular}

Dari Tabel 2 terlihat terjadi peningkatan ratarata pada kondisi awal (yaitu data dari hasil belajar kimia tahun 2008), siklus I dan siklus II yaitu dari 57, 63 menjadi 73. Begitu juga untuk ketuntasan belajar klasikal terjadi peningkatan, siswa yang tuntas belajar dari sebelumnya pada kondisi awal ada 26 dari 40 siswa, siklus I ada 21 dari 40 siswa dan siswa yang tuntas belajar menjadi 30 dari 40 siswa yang tuntas belajar pada siklus II. Secara keseluruhan, hasil pelaksanaan siklus I dan II dan indicator keberhasilannya dapat dilihat pada Tabel 3. berikut.

Tabel 3. Hasil Penelitian dan Indikator Keberhasilan

\begin{tabular}{|l|l|l|l|l|}
\hline & Siklus I & Siklus II & Indikator eberhasilan & Keterangan \\
\hline Keaktifan Siswa & $65 \%$ & $86 \%$ & $\geq 71 \%$ & Tercapai \\
\hline a. Rata-rata & 65 & 75 & $\geq 70$ & Tercapai \\
\hline b. Ketuntasan & 26 siswa & 30 siswa & $\geq 26$ & Tercapai \\
\hline
\end{tabular}

Dari data di atas, 3 aspek penelitian telah memenuhi indikator keberhasilan yang telah ditetapkan. Peningkatan tersebut membuktikan keberhasilan penerapan pembelajaran kontekstual dengan metode kerja kelompok. Pada pembelajaran kontekstual, siswa dipandang sebagai individu yang sedang berkembang. Kemampuan belajar akan sangat ditentukan oleh tingkat perkembangan dan pengalaman mereka. Peran guru tidak lagi sebagai instruktur melainkan sebagai pembimbing siswa agar

mereka dapat belajar sesuai dengan kemampuannya. Selain itu, salah satu metode kerja kelompok sebagai alat bantu untuk memudahkan pemahaman siswa dalam mempelajari materi ikatan kimia karena didesain khusus agar siswa lebih bisa berkomunikasi sdengan temanya sehingga bisa lebih paham dan meberikan contoh-contoh materi yang kontekstual.

Dari langkah-langkah yang sudah diajarkan dalam pembelajaran ini peneliti dan guru sudah melaksanakan pembelajaran dengan pendekatan 
kontekstual dengan metode kerja kelompok dengan merealisasikan tujuh komponen pendekatan kontekstual

1. Konstruktivisme (Constructivism), dalam komponen ini guru sudah melakukanya,memfasilitasi siswa untuk membangun pengetahuan baru mengenai materi ikatan kimia dan aplikasinya terhadap kehidupan seharihari

2. Menemukan (inquiri), dalam komponen ini siswa melakukan proses mencari dan menemukan jawaban permasalahan yang berhubungan dangan materi ikatan kimia dan aplikasinya terhadap kehidupan seharihari

3. Bertanya (Questioning), dalam komponen ini siswa sudah menerapkanya dengan saling bertanya mengenai materi ikatan kimia baik kepada temanya maupun kepada guru

4. Masyarakat Belajar, dalam komponen ini siswa melakukanya dengan cara bekerja secara kelompok dalam menyelesaikan tugas guru

5. Pemodelan (Modeling), dalam komponen ini guru membuat sebuah model pembelajaran yaitu dengan cara memperagakan sebuah contoh ikatan kimia yang ada dalam kehidupan nyata sehingga siswa lebih mudah memahaminya

6. Refleksi, dalam komponen ini siswa di tuntut oleh guru untuk berpikir sejenak mengenai materi yang sudah di ajarkanya dan sekaligus pengaplikasianya terhadap kehidupan sehari-hari

7. Penilain yang sebenarnya, dalam komponen ini seorang guru memberikan poin atau nilai bagi siswa yang aktif bertanya maupun menjawab.

Dari penelitian yang telah dilakukan ini, hasil belajar siswa dan peran aktif siswa dan kinerja guru dapat meningkat. Dengan demikian, penerapan pembelajaran kontekstual dengan metode kerja kelompok ini dapat diterapkan di MAN Kota Sorong, sebagai salah satu alternatif untuk mengatasi permasalahan pembelajaran kimia.

\section{KESIMPULAN}

Penerapan pendekatan kontekstual dengan metode kerja kelompok dapat meningkatkan hasil belajar siswa pada pembelajaran materi pokok ikatan kimia siswa kelas X MAN Kota Sorong. Keberhasilan penerapan model pembelajaran melalui pendekatan kontekstual dengan metode kerja kelompok sebagai upaya untuk meningkatkan hasil belajar siswa di kelas X MAN Kota Sorong ditunjukkan dengan adanya perubahan dalam proses pembelajaran yaitu keaktifan pada saat proses pembelajaran, juga ditunjukkan adanya peningkatan nilai skor tes akhir dari masingmasing siklus. Hal ini dapat dilihat dari perolehan skor yang diperoleh melalui pengamatan tentang keaktifan belajar siswa dengan indikator keaktifan dalam proses pembelajaran. Suatu kelas dikatakan tuntas belajar bila kelas tersebut telah terdapat 30 siswa dari jumlah siswa yaitu 40 yang memperoleh nilai ${ }^{3} 65$, dan ratarata hasil belajar $\geq 70$, Pembelajaran siswa dikatakan berhasil jika keaktifan siswa memperoleh prosentase $\geq$ $71 \%$, Kemampuan guru dalam pelaksanaan pembelajaran sesuai dengan model pembelajaran kontekstual dengan menggunakan metode kerja kelompok dikatakan berhasil jika kemampuan guru memperoleh prosentase $\geq 71 \%$. Rata-rata hasil belajar pada siklus I 67 dan, pada siklus I keaktifan siswa sebesar $65 \%$. Kinerja guru pada siklus I memperoleh nilai $62 \%$. Dilihat dari indikator keberhasilan, siklus I belum berhasil dan perlu perbaikan pada siklus II. Rata-rata hasil belajar pada siklus II 73. Sedangkan keaktifan siswa sebesar $86 \%$ dan kinerja guru sebesar $84 \%$. Maka pada siklus II sudah berhasil.

\section{DAFTAR PUSTAKA}

Amirul Hadi dan Haryono, (2005). Metodologi Penelitian Pendidikan, Bandung: Pustaka Setia,.

Aqib, Zainal, (2007). Penelitian Tindakan Kelas: untuk guru, Bandung : Yrama Widya,.

Azwar, Saifuddin, (2007). Metode Penelitian, Yogyakarta : Pustaka Pelajar,

Baharuddin dan Esa Nur Wahyuni, (2008). Teori Belajar dan Pembelajaran, Yogjakarta: Arruz Media,.

Chang, Raymond, (2006). Kimia Dasar : KonsepKonsep Inti, terj. Dept. Kimia ITB, Jilid I, Jakarta : Erlangga,

E. Mulyasa, (2005). Implementasi Kurikulum 2004 Panduan Belajar KBK , Bandung: Remaja Rosda Karya,.

Hasbulah, (2005). Dasar-Dasa Ilmu Pendidikan, Jakarta: PT Raja Grafindo Persada,

Ismail SM, (2008). Strategi Pembelajaran Agama Islam Berbasis PAIKEM, Semarang: Rasail Media Group,.

Johnson, Elaine B, (2007). Contextual Teaching and Learning Menjadikan Kegiatan Belajar Mengajar Mengasyikkan dan Bermakna, terj. Ibnu Setiawan, Bandung: MLC, 